\title{
Implementasi Metode Eksperimen untuk Meningkatkan Prestasi Belajar Menggambar Realis pada Siswa Sekolah Menengah Pertama Negeri 1 Ponorogo
}

\author{
Belinda Dewi Regina \\ Fakultas Keguruan dan Ilmu Pendidikan, Universitas Muhammadiyah Malang \\ sofiamadiun@gmail.com
}

\begin{abstract}
Sekolah Menengah Pertama Negeri 1 Ponorogo merupakan salah satu sekolah di Ponorogo yang mana mengajarkan gambar realis dalam mata pelajaran Seni Budaya. Berdasarkan wawancara dengan guru dan beberapa siswa bahwa prestasi belajar menggambar realis cenderung lebih rendah dibandingkan materi pelajaran Seni Budaya yang lain seperti menggambar kartun. Hal ini ditunjukkan dengan perilaku anak yang selalu membuat kesal para guru saat pembelajaran berlangsung. Sebagian besar siswa tidak tertarik terhadap pembelajaran ini disebabkan rasa jenuh dan kurangnya kemampuan mereka dalam menggambar. Melihat fenomena seperti yang dipaparkan di atas, peneliti tertarik untuk melakukan penelitian "Implementasi Metode Eksperimen untuk Meningkatkan Prestasi Belajar Menggambar Realis pada Siswa Sekolah Menengah Pertama Negeri 1 Ponorogo". Tujuan penelitian ini (1) Mendiskripsikan proses Implementasi Metode Eksperimen untuk Meningkatkan Prestasi Belajar Menggambar Realis pada Siswa SMPN 1Ponorogo. (2) Mendiskripsikan seberapa besar perbedaan penggunaan metode Eksperimen dengan metode pembelajaran sebelumnya untuk meningkatkan prestasi belajar menggambar realis pada siswa SMPN 1 Ponorogo. Penelitian ini merupakan Penelitian Tindakan Kelas dengan pendekatan deskriptif kualitatif. Teknik pengumpulan data dilakukan melalui pengamatan, wawancara, angket dan studi dokumentasi. Dengan jumlah siswa kelas VIII B 25 siswa yang terdiri dari 17 putri dan 8 putra, metode eksperimen menggunakan siklus I dan siklus II, didapatkan nilai rata-rata siklus I : 81,8 , dan siklus II : 85,6. Dengan menggunakan metode eksperimen membuktikan adanya peningkatan nilai sebanyak 3,8. Dalam hal ini peneliti menemukan bahwa dengan menggunakan metode eksperimen untuk pembelajaran menggambar realis dapat meningkatkan prestasi belajar dibandingkan metode yang digunakan sebelumnya yaitu metode diskusi.
\end{abstract}

Kata kunci: metode eksperimen, prestasi belajar, menggambar realis

\section{Implementation of Experimental Methods to Increase Learning Achievements Forms Of Study on Student School Students First 1 Ponorogo}

State Junior High School 1 Ponorogo is one of the schools in Ponorogo that teaches realist images in Arts and Culture subjects. Based on interviews with teachers and some students that learning achievement of realist drawing tends to be lower than other subjects of Arts and Culture such as drawing cartoons. This is indicated by the behavior of children who always upset the teachers while learning takes place. Most students are not interested in this learning due to their saturation and lack of ability in drawing. Seeing the phenomenon as described above, researchers are interested to conduct research "Implementation of Experimental Methods to Increase Achievement of Realist Drawing Learning at Junior High School Students 1 Ponorogo". The purpose of this research (1) to describe the process of Implementation of Experimental Method to Increase Achievement of Realistic Drawing Learning on Junior High School Students 1 Ponorogo. (2) to describe how much difference of experiment method use with previous learning method to improve learning achievement of realist drawing on students of SMPN 1 Ponorogo. This research is a Classroom Action Research with qualitative descriptive approach. Data collection techniques are conducted through observation, interviews, questionnaires and documentation studies. With the number of students of class VIII B 25 students consisting of 17 daughters and 8 sons, the experimental method using cycle I and cycle II, obtained the average value of cycle I : 81.8 , and cycle II : 85.6. Using the experimental method proves an increase in value of 3.8. In this case the researchers found that by using the experimental method for realist drawing learning can improve learning achievement than the method used previously is the method of free copyrights.

Keywords : Experimental Method, Learning Achievement, Drawing Realist 


\section{PENDAHULUAN}

Peran pendidikan sangat penting untuk menciptakan kehidupan yang cerdas, damai, terbuka dan demokratis. Pendidikan tidak hanya mencakup pengembangan intelektualitas saja. Pendidikan lebih ditekankan pada proses pembinaan kepribadian anak didik secara menyeluruh (Sagala, 2009:3). Tugas pendidikan yaitu membina dan membawa anak didik ke arah kemajuan. Pendidikan harus menghasilkan manusia yang cakap, aktif, dan kreatif.

Guru berperan penting dalam hal menciptakan lingkungan yang aktif dan kreatif. Guru juga harus mampu mendorong siswa melakukan interaktif yang produktif dan memberikan pengalaman belajar yang dibutuhkan (Syaodih,1997:105). Peranan guru dalam meningkatkan mutu pendidikan memang besar, hal tersebut dapat dipahami dari hakikat guru sebagai pendidik. Oleh sebab itu guru harus peka terhadap perubahan yang terjadi, khususnya dalam bidang pendidikan dan pembelajaran karena ilmu pengetahuan yang terus berkembang. Menurut (Sudjana, 2005:19) menjelaskan bahwa tugas dan tanggung jawab seorang guru erat kaitannya dengan kompetensi yang harus dimilikinya dalam menjalankan profesi tersebut. Pendidik, peserta didik, dan tujuan pendidikan tetap menjadi komponen utama dalam pendidikan (Syaodih, 1997:191).

SMPN1 Ponorogo merupakan salah satu sekolah di Ponorogo yang mengajarkan gambar realis, karena kurangnya antusias siswa dalam pembelajaran menggambar realis, peneliti tertarik untuk menjadikan sekolah ini sebagai bahan untuk diteliti. Pembelajaran menggambar realis di sekolah ini kurang begitu digemari oleh sebagian besar siswa dibandingkan materi Seni Budaya yang lain. Hasil observasi penulis melalui wawancara dengan guru dan beberapa siswa sebagai sampel di SMPN 1 Ponorogo, prestasi belajar pada materi menggambar realis cenderung lebih rendah bila dibandingkan dengan materi pelajaran Seni Budaya yang lain.

Sebagian besar siswa tidak tertarik terhadap pembelajaran menggambar realis didasarkan pada rasa jenuh. Hampir seluruh siswa di SMPN1 Ponorogo tersebut pernah mengalami kebosanan dalam pembelajaran menggambar realis. Ada banyak hal yang menyebabkan kejenuhan dalam proses pembelajaran tersebut, diantaranya yakni persepsi negatif siswa terhadap materi menggambar. Siswa-siswa kurang memiliki kemampuan dalam menggambar, pelajaran ini dianggap pelajaran yang tidak begitu menarik. Ada yang beranggapan bahwa menggambar realis sebagai momok sehingga siswa malas untuk bersekolah.

Kekurangantusiasan siswa serta ketidaksiapan siswa dalam menerima materi pelajaran menggambar realis terwujud dalam tindakan seperti tidak membawa perlengkapan atau peralatan menggambar, tidak memperhatikan guru, atau melalaikan tugas yang diberikan oleh guru. Sebagai akibatnya penguasaan materi menggambar realis oleh siswa kurang dikuasai dengan baik, sementara materi tersebut merupakan materi dasar untuk masuk ke dalam pengembangan materi menggambar yang lebih kompleks. Lebih lanjut seperti yang diungkapkan (Sumanto, 2008:70) bahwa menggambar adalah kegiatan manusia untuk mengungkapkan apa yang dirasakan dan dialaminya baik mental maupun visual dalam bentuk garis dan warna.

Berdasarkan latar belakang masalah yang dikemukakan diatas terdapat tujuan penelitian, tujuan penelitian tersebut antara lain: (1) Mendiskripsikan proses Implementasi Metode Eksperimen untuk Meningkatkan Prestasi Belajar Menggambar Realis pada Siswa SMPN 1 Ponorogo. (2) Mendiskripsikan seberapa besar perbedaan penggunaan metode Eksperimen dengan metode pembelajaran sebelumnya untuk meningkatkan prestasi belajar menggambar realis pada siswa SMPN 1 Ponorogo.

Adapun kontribusi yang terdapat dalam penelitian ini masuk ke dalam manfaat teoretis dan manfaat praktis. Manfaat teoretis dan manfaat praktis sebagai berikut : (1) Secara teoretis. Hasil penelitian ini dapat dijadikan sebagai sumbangan pemikiran untuk penelitian dan dasar untuk pengembangan teori tentang Implementasi Metode Eksperimen untuk Meningkatkan Prestasi Belajar Menggambar Realis serta menambah pengetahuan, wawasan bagi pengembangan keilmuan dan kajian-kajian teoretis tentang pembelajaran Seni Budaya. (2) Manfaat praktis. Secara praktis penelitian ini memberikan manfaat bagi peneliti, guru, dan bagi peneliti lain. Diantaranya sebagai berikut: (1)Bagi Peneliti.Hasil penelitian ini dapat menambah wawasan dan pengetahuan dalam bidang penelitian khususnya tentang Implementasi Metode Eksperimen untuk Meningkatkan Prestasi Belajar Menggambar Realis pada pembelajaran Seni Budaya, serta merupakan sarana pengaplikasian dalam mengajar yang diperoleh di bangku kuliah ke dalam dunia empiris di lapangan. (2) Bagi Guru di sekolah. Hasil penelitian ini dapat dijadikan acuan dan informasi yang berharga untuk meningkatkan kreativitasnya serta hasil penelitian ini dapat juga digunakan untuk meningkatkan interaksi guru dengan siswa dalam proses pembelajaran menggambar kartun serta menambah materi tentang seni melalui Seni Budaya. (3) Bagi Peneliti Lain . Penelitian ini dapat dijadikan sebagai bahan perbandingan dalam melakukan peneliti-penelitian yang sejenis. Selain itu, peneliti lanjutan dapat mengembangkan teori tentang Implementasi Metode Eksperimen untuk Meningkatkan Prestasi Belajar Menggambar Realis dalam pembelajaran Seni Budaya.

\section{METODE PENELITIAN}

Penelitian berjudul "Implementasi Metode Eksperimen untuk Meningkatkan Prestasi Belajar Menggambar Realis pada Siswa SMPN 1 Ponorogo" bertujuan untuk mengetahui bagaimana pengimplementasian metode eksperimen 
untuk meningkatkan prestasi belajar gambar realis. Berdasarkan tujuan tersebut, maka penelitian ini menggunakan pendekatan deskriptif kualitatif.

Penelitian ini dilaksanakan di SMPN 1 Ponorogo. Pemilihan lokasi penelitian tersebut karena sekolah tersebut merupakan sekolah unggulan atau favorit di kota Ponorogo sehingga masyarakat memiliki pandangan bahwa mutu pendidikan dan mutu pengajar serta pelajar di sekolah tersebut lebih tinggi dibanding sekolah negeri lainnya. Lokasi penelitian ini bertempat di Jalan Soekarno Hatta No.82, Bangunsari, Kec. Ponorogo, Kabupaten Ponorogo, Jawa Timur 63411.

Sasaran penelitian ini adalah guru dan siswa Seni Budaya yang mengadakan pembelajaran Seni Budaya yang ada di SMPN 1 Ponorogo. Dalam hal ini yang menjadi fokus penelitian adalah pembelajaran seni rupa sub bab menggambar realis dan implementasi metode eksperimen. Hal tersebut meliputi pengaplikasian metode dan sumber pembelajaran, pengelolaan kelas, pengelolaan interaksi belajar mengajar, dan penilaian proses dan hasil belajar siswa. Adapun siswa yang akan dijadikan objek penelitian adalah siswa kelas VIII B yang mengambil pilihan pembelajaran Seni Budaya sub menggambar realis.

Penelitian ini menghasilkan data-data mengenai informasi implementasi metode eksperimen menggambar realis. Sumber data dalam penelitian ini adalah guru Seni Budaya di SMPN 1 Ponorogo yang mengajar mata pelajaran Seni Budaya kelas VIII dan siswa kelas VIII B terpilih (siswa yang mengikuti materi Seni Budaya) dari SMPN 1 Ponorogo.

Teknik pengumpulan data yang dilakukan peneliti, pertama adalah terjun dalam kelas ketika guru mengajar pembelajaran menggambar realis yaitu dengan cara mengadakan observasi untuk mengamati bagaimana proses implementasi metode eksperimen dalam meningkatkan prestasi belajar menggambar realis. Pengamatan ini dilakukan dengan menggunakan lembar observasi. Kedua, diskusi langsung dengan guru mata pelajaran Seni Budaya dengan cara melakukan wawancara terstruktur di lokasi penelitian (enquiring). Ketiga, melakukan pengambilan data berupa penyebaran angket untuk mengetahui respon siswa dan kemudian melakukan analisis dokumen dan catatan lapangan (examining).

\section{ANALISIS DAN INTEPRETASI DATA}

SMPN 1 Ponorogo terletak di Jalan Soekarno Hatta No.82, Bangunsari, Kec. Ponorogo, Kabupaten Ponorogo, Jawa Timur 63411. SMPN 1 Ponorogo mendapat kepercayaan masyarakat kota Ponorogo dan sekitarnya sebagai SMP terfavorit di Ponorogo. Dengan kurun waktu yang cukup lama SMPN 1 Ponorogo telah berhasil mencetak gener- asi-generasi yang unggul dan kompeten di pemerintahan maupun non pemerintahan, bidang Seni Budaya, dan juga dalam bidang teknologi.

Sebagai sekolah kebanggaan kota Ponorogo, SMPN 1 Ponorogo memiliki fasilitas yang lengkap untuk menunjang sarana belajar siswa. Sarana tersebut meliputi fasilitas ruang kesenian diantaranya seni musik, tari, gamelan dan seni rupa, laboratorium IPA, laboratorium IPS, perpustakaan, ruang multimedia, laboratorium bahasa, laboratorium komputer, dan aula yang biasanya digunakan untuk tempat rapat besar. Dari data yang telah dihimpun peneliti selama di lapangan diperoleh keterangan bahwa ada enam kelas yang mengikuti pembelajaran Seni Budaya dengan jumlah siswa yang berbeda-beda di tiap kelas. Secara keseluruhan kelas VIII yang mengikuti pembelajaran Seni Budaya (rupa) berjumlah 150 siswa.

Proses Implementasi Metode Eksperimen untuk Meningkatkan Prestasi Belajar Menggambar Realis pada Siswa SMP Negeri 1 Ponorogo.

Implementasi metode eksperimen dalam pembelajaran menggambar realis bersifat objektif, seperti ilmu pengetahuan alam, baik dilakukan di dalam kelas, di luar kelas maupun dalam suatu laboratorum tertentu. Berikut langkah-langkah implementasi metode eksperimen : (1) Percobaan awal, pembelajaran diawali dengan melakukan percobaan yang didemonstrasikan guru atau dengan mengamati fenomena alam yang terdapat disekitar tempat tinggal atau sekolah. Demonstrasi ini menampilkan masalah-masalah yang berkaitan dengan objek gambar realis yang akan digambar.(2) Pengamatan, merupakan kegiatan siswa saat guru melakukan percobaan dengan memberikan contoh benda yang akan digambar. Siswa diharapkan mengamati dan menggambar objek disekitar lingkungan sekolah.(3) Hipoteis awal, siswa dapat memikirkan gambaran (membuat konsep yang akan digambar) sementara berdasarkan hasil pengamatannya.(4) Verifikasi, kegiatan untuk membuktikan gambar yang sudah diamati dan dilakukan melalui kerja individu. Siswa diharapkan memiliki gambaran (konsep gambar) dan mengaplikasikan dalam kertas gambar, selanjutnya dapat diketahui hasilnya. (5) Aplikasi konsep, siswa memiliki gambaran (konsep) dan hasilnya diaplikasikan dalam sebuah kertas gambar. Kegiatan ini merupakan pemantapan konsep yang telah dipelajari.(6) Evaluasi, merupakan kegiatan akhir setelah selesai satu konsep.

Selain itu implementasi metode eksperimen juga dimulai dari aspek kesiapan guru. Sebelum proses pembelajaran, yang dilakukan oleh seorang guru adalah mempersiapkan perangkat pembelajaran. Perangkat pembelajaran dalam hal ini pemetaan materi, Penyusunan Program Tahunan, Penyusunan Program Semester, pembuatan Silabus dan Rencana Program Pembelajaran, pemberian tugas, serta rubrik penilaian. Di mulai dari Penyusunan Program Tahunan. Program Tahunan ini dilakukan oleh guru sebagai 
hasil analisis terhadap KTSP 2006 dan Program Tahunan ini didasarkan pada kemampuan anak dan potensi yang akan dikembangkan oleh anak didik sebagai bekal dalam kehidupan. Program Tahunan ini berdasarkan pada standart Kompetensi Dasar yang ada dalam KTSP 2006, serta materi-materi yang berdasarkan pada kegiatan apresiasi dan kreasi. Materi yang sesuai dengan potensinya memudahkan guru dalam mengontrol perkembangan anak didik.

Standart Kompetensi dan Kompetensi Dasar yang ada dalam KTSP 2006 dibagi berdasarkan pada kegiatan yang berhubungan dengan apresiasi dan kreasi yang mana tujuan nya untuk mengetahui materi mana yang masuk dalam kegiatan kreasi maupun apresiasi. Kegiatan kreasi meliputi kegiatan proses karya atau penciptaan karya, sedangkan kegiatan apresiasi berhubungan dengan kegiatan kreatif, pengamatan terhadap karya. Adapun Program Tahunan yang digunakan oleh guru berdasarkan format Program Tahunan, yang meliputi: a). Standart Kompetensi, b). Kompetensi Dasar, c). Indikator, d). Aspek Penilaian, e). Lembar Program Tahunan. Setelah Program Tahunan, langkah selanjutnya Penyusunan Program Semester. Program Semester ini dibuat berdasarkan pada Kompetensi Dasar yang telah dipetakan dalam Program Tahunan. Penyusunan Program Semester ini merupakan kegiatan pemetaan pada alokasi waktu. Pembuatan Program Semester juga berdasar pada minggu efektif yang ada dalam kalender pendidikan. Format Program Semester yang digunakan adalah sebagai berikut: a). Semester ganjil atau genap, b) Standar Kompetensi, c) Kompetensi Dasar, d). Alokasi waktu, e). Keterangan.

Alokasi waktu yang digunakan berdasarkan pada analisa Kompetensi Dasar yang kemudian disesuaikan dengan materi yang akan diberikan. Kemudian diuraikan secara garis besar pada Silabus dengan memperhatikan alokasi waktu yang digunakan dalam penyampaian materi selama satu semester. Pembuatan Program Semester selain untuk mengetahui Kompetensi Dasar yang akan diberikan juga sebagai pegangan guru dalam menyampaikan materi ajar, dan berguna untuk mengontrol waktu dalam proses belajar. Lembar Program Semester. Setelah pembuatan Program Semester, langkah selanjunya yaitu Pembuatan Silabus dan Rencana Program Pembelajaran.

Pembuatan Silabus dan Rencana Program Pembelajaran merupakan kegiatan yang dilakukan oleh guru setelah membuat Program Semester. Pembuatan Silabus dan Rencana Program Pembelajaran berdasarkan pada pemetaan terhadap Kompetensi Dasar dan alokasi waktu pada Program Semester.

Format Silabus yang dikembangkan adalah sebagai berikut a). Standar Kompetensi, b). Kompetensi Dasar, c). Indikator, d). Materi pokok dan uraian nya, e). Pengalaman belajar, f). Penilaian, jenis tagihan, bentuk instrumen, g). Alokasi waktu dan, h). Sumber pembelajaran.
Dalam pembuatan Silabus dan Rencana Program Pembelajaran yang mendapat perhatian cukup adalah mengenai materi pembelajaran dan strategi pembelajaran, baik metode dan alokasi waktu. Silabus dan Rencana Program Pembelajaran yang telah dibuat tidak dapat langsung dijadikan bekal dalam pengajaran, sebab penjabaran dalam Silabus masih secara rinci tentang materi maupun strategi pembelajaran yang digunakan untuk bekal mengajar adalah satuan acara pengajaran. Lembar Silabus dan Rencana Program Pembelajaran. Setelah membuat Silabus dan Rencana Program Pembelajaran, langkah selanjutnya yaitu Pembuatan Soal Tugas, kemudian Pembuatan Rubrik Penilaian dan terakhir menyiapkan media yang disiapkan guru.

Perbedaan penggunaan metode Eksperimen dengan metode pembelajaran sebelumnya untuk meningkatkan prestasi belajar menggambar realis pada siswa SMP Negeri 1 Ponorogo

Data hasil tes belajar siswa kelas VIIIB dalam pembelajaran gambar realis setelah menerapkan metode eksperimen pada siklus pertama

Adapun analisis nilai rata-rata dan persentase hasil belajar siswa berdasarkan hasil tes belajar diatas digunakan perhitungan sebagai berikut:

Nilai siklus pertama:

Nilai rata-rata hasil belajar siswa setelah menerapkan metode eksperimen

$$
\begin{aligned}
& \mathrm{M}=\sum_{\mathrm{N}}^{\mathrm{fx}}: \ldots \\
& \mathrm{M}=\sum_{2.5}^{2045}: \ldots \\
& \mathrm{M}=81,8
\end{aligned}
$$

Persentase ketuntasan hasil belajar setelah menerapkan metode eksperimen

$$
\begin{aligned}
\mathrm{T} & =\frac{\mathrm{X}}{\mathrm{N}} \times 100 \% \\
\mathrm{~T} & =\frac{25}{25} \times 100 \% \\
\mathrm{~T} & =100 \%
\end{aligned}
$$

Dengan demikian diketahui bahwa jumlah siswa yang terdaftar pada kelas VIII B adalah 25 siswa yang terdiri dari 17 putri dan 8 siswa putra. Pre test praktek menggambar oleh 25 siswa dengan jumlah total nilai 2045 dengan nilai rata-rata 81,8 dan siswa yang tuntas belajar dalam pembelajaran menggambar realis setelah diterapkan metode eksperimen sebanyak 25 dengan persentase ketuntasan belajar $100 \%$.

Dengan demikian dapat disimpulkan bahwa dengan nilai rata-rata 81,8 dan siswa yang tuntas belajar adalah $100 \%$. Hal ini berarti nilai mereka sudah mencapai nilai ketuntasan minimal yang telah ditentukan oleh sekolah yaitu 75 . 


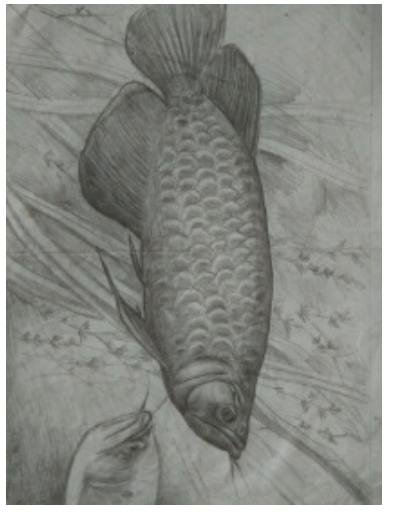

\section{Gambar 1}

Nama : Nihaya Nur Arifah

Nis $: 15$

Judul : Ikan Nirwana

Termasuk dalam kategori tinggi dengan skor nilai 85 . Dilihat dari bentuk gambar memperlihatkan $70 \%$ bentuk gambarnya mendekati realis (15 point). Dilihat dari kesatuan gambarnya (20 point) ini karena gambar ini menunjukkan lebih terorganisir atau lebih ada kesatuan dibandingkan dengan karya lain. Dilihat dari kerapian (20 point) ini karena dalam memberi aksiran lebih rapi, sehingga beberapa komposisi warna gelap terangnya mengandung keindahan.Sedangkan dilihat dari originalitas / non originalitas (keaslian) mendapat (30 point) karena menujukkan banyak keaslian.

Jadi total nilai karya realis diatas adalah 85

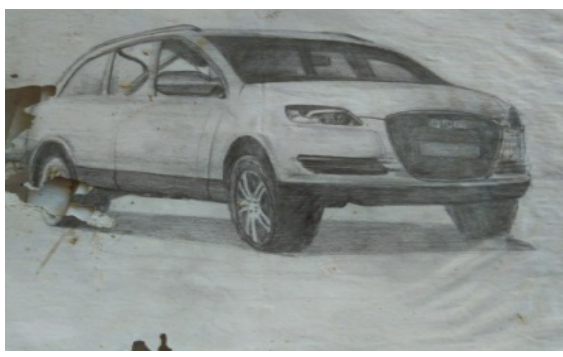

\section{Gambar 2}

Nama : Zain Muttaqi

Nis $: 25$

Judul :Mobil

Termasuk dalam kategori sedang dengan skor nilai 80 . Dilihat dari bentuk gambar memperlihatkan $60 \%$ bentuk gambarnya kurang realis (10 point). Dilihat dari kesatuan gambarnya (20 point) ini karena gambar ini kurang menunjukkan kesatuan dalam menggambar dibandingkan dengan karya lain. Dilihat dari kerapian (20 point) ini karena dalam memberi aksiran lebih rapi. Sedangkan dilihat dari originalitas / non originalitas (keaslian) mendapat (30 point) karena kurang begitu menujukkan banyak keaslian. Jadi total nilai karya gambar realis diatas adalah 80

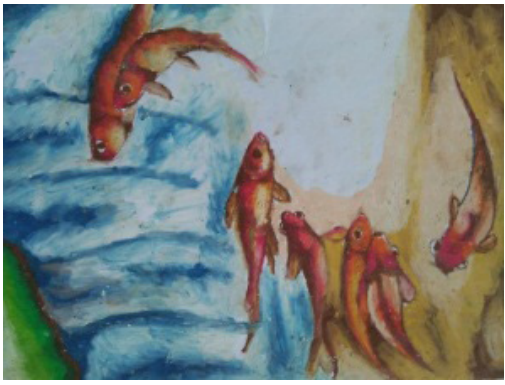

Gambar 3

Nama : Andy Dwi Cahyo

Nis :03

Judul :Ikan

Termasuk dalam kategori kurang dengan skor nilai 78 . Dilihat dari bentuk gambar memperlihatkan $50 \%$ bentuk gambarnya sangat kurang bervariasi (13 point). Dilihat dari kesatuan gambarnya (20 point) ini karena gambar ini sangat kurang menunjukkan kesatuan dalam menggambar dibandingkan dengan karya lain. Dilihat dari kerapian (15 point) ini karena dalam mewarnai sangat kurang rapi, sehingga beberapa komposisi warnanya kurang mengandung keindahan. Sedangkan dilihat dari originalitas / non originalitas (keaslian) mendapat (30 point) karena sangat kurang menujukkan banyak keaslian.

Jadi total nilai karya gambar realis diatas adalah 78

2. Data hasil tes belajar siswa kelas VIIIB dalam pembelajaran gambar realis setelah menerapkan metode eksperimen pada siklus ke 2

Adapun analisis nilai rata-rata dan persentase hasil belajar siswa berdasarkan hasil tes belajar diatas digunakan perhitungan sebagai berikut:

Nilai siklus kedua:

Nilai rata-rata hasil belajar siswa setelah menerapkan metode eksperimen

$$
\begin{aligned}
& M=\sum_{\mathrm{N}}^{\mathrm{fx}}: \\
& \mathrm{M}=\sum_{25}^{2140}: \mathbf{m} \\
& \mathrm{M}=85,6
\end{aligned}
$$

Persentase ketuntasan hasil belajar setelah menerapkan metode eksperimen

$$
\begin{aligned}
\mathrm{T} & =\frac{\mathrm{X}}{\mathrm{N}} \times 100 \% \\
\mathrm{~T} & =\frac{25}{25} \times 100 \% \\
\mathrm{~T} & =100 \%
\end{aligned}
$$

Dengan demikian diketahui bahwa jumlah siswa yang terdaftar pada kelas VIII B adalah 25 siswa yang terdiri dari 17 putri dan 8 siswa putra. Pre test praktek menggambar oleh 25 siswa dengan jumlah total nilai 2140 dengan nilai rata-rata 85,6 dan siswa yang tuntas belajar dalam pembelajaran menggambar realis setelah diterapkan metode eksperimen sebanyak 25 dengan persentase ketuntasan belajar $100 \%$ 
Dengan demikian dapat disimpulkan bahwa dengan nilai rata-rata 85,6 dan siswa yang tuntas belajar adalah $100 \%$. Hal ini berarti nilai mereka sudah mencapai nilai ketuntasan minimal yang telah ditentukan oleh sekolah yaitu 75 .

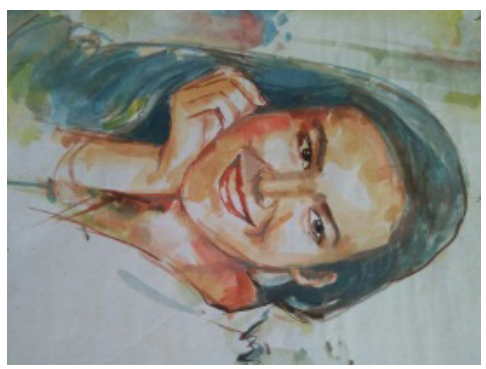

\section{Gambar 1}

Nama : Dynda Kharisma

Nis :08

Judul :Perempuan

Termasuk dalam kategori tertinggi dengan skor nilai 90 . Dilihat dari bentuk gambar memperlihatkan $80 \%$ bentuk gambarnya bervariasi (20 point). Dilihat dari kesatuan gambarnya (20 point) ini karena gambar ini menunjukkan lebih terorganisir atau lebih ada kesatuan dibandingkan dengan karya lain. Dilihat dari kerapian (20 point) ini karena dalam mewarnai lebih rapi, sehingga beberapa komposisi warnanya mengandung keindahan. Sedangkan dilihat dari originalitas / non originalitas (keaslian) mendapat (30 point) karena menujukkan banyak keaslian. Jadi total nilai karya gambar realisnya diatas adalah 90

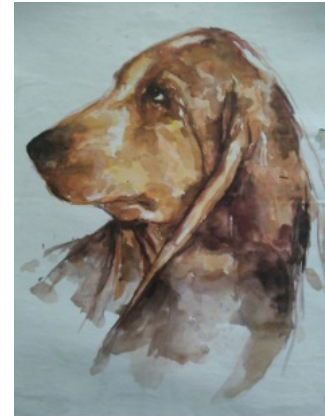

\section{Gambar 2}

Nama : Naha Navisa

Nis $: 13$

Judul :Anjing

Termasuk dalam kategori tinggi dengan skor nilai 85 . Dilihat dari bentuk gambar memperlihatkan $60 \%$ bentuk gambarnya kurang bervariasi (10 point). Dilihat dari kesatuan gambarnya (20 point) ini karena gambar ini kurang menunjukkan kesatuan dalam menggambar dibandingkan dengan karya lain.

Dilihat dari kerpaian (25 point) ini karena dalam kurang mewarnai kurang begitu rapi. Sedangkan dilihat dari originalitas / non originalitas (keaslian) mendapat (30 point) karena kurang menujukkan banyak keaslian.
Jadi total nilai karya gambar realis diatas adalah 85

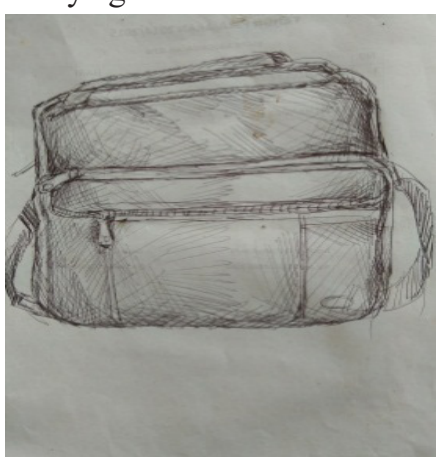

\section{Gambar 3}

Nama : Syaifulizan Nur Ikhsan

Nis $\quad: 20$

Judul :Tas

Termasuk dalam kategori rendah dengan skor nilai 80 . Dilihat dari bentuk gambar memperlihatkan $50 \%$ bentuk gambarnya sangant kurang bervariasi (15 point). Dilihat dari kesatuan gambarnya (20 point) ini karena gambar ini sangat kurang menunjukkan kesatuan dalam menggambar dibandingkan dengan karya lain. Dilihat dari kerapian (25 point) ini karena dalam mengaksir sangat kurang rapi, sehingga beberapa komposisi warnanya kurang mengandung keindahan. Sedangkan dilihat dari originalitas / non originalitas (keaslian) mendapat (20 point) karena sangat kurang menujukkan banyak keaslian. Jadi total nilai karya gambar realis diatas adalah 80 .

Peningkatan hasil belajar siswa mulai dari pra siklus, siklus pertama dan siklus kedua. Peningkatan hasil tes belajar siswa kelas VIIIB setelah menerapkan metode eksperimen dari pra siklus, siklus pertama dan siklus kedua mengalami peningkatan.

Adapun analisis nilai rata-rata dan persentase hasil belajar siswa berdasarkan hasil tes belajar dari pra siklus, siklus pertama dan siklus kedua diatas digunakan perhitungan sebagai berikut:

Perbandingan Hasil Belajar Siswa dari pra siklus, siklus pertama dan siklus kedua dalan menerapkan metode eksperimen.

Tabel 1. Perbandingan Hasil Belajar Siswa dari pra siklus, siklus pertama dan siklus kedua

\begin{tabular}{llcccc}
\hline No & Nama siswa & $\begin{array}{c}\text { Pra } \\
\text { siklus }\end{array}$ & $\begin{array}{c}\text { Siklus } \\
\text { I }\end{array}$ & $\begin{array}{c}\text { Siklus } \\
\text { II }\end{array}$ & Keterangan \\
\hline 1 & $\begin{array}{l}\text { Abdul Ghofur } \\
\text { Sugiarta }\end{array}$ & 70 & 83 & 89 & Meningkat \\
\hline & & & & & \\
\hline & Ajis Sadewo & 70 & 84 & 85 & Meningkat \\
\hline & $\begin{array}{l}\text { Andy Dwi } \\
\text { Cahyo }\end{array}$ & 74 & 80 & 86 & Meningkat \\
\hline
\end{tabular}




\begin{tabular}{|c|c|c|c|c|c|}
\hline 4 & $\begin{array}{l}\text { Azizah Ayu } \\
\text { Anggraini }\end{array}$ & 74 & 81 & 84 & Meningkat \\
\hline 5 & $\begin{array}{l}\text { Badiq } \\
\text { Mu'afidda }\end{array}$ & 73 & 83 & 86 & Meningkat \\
\hline 6 & $\begin{array}{l}\text { Diah Ayu } \\
\text { Megawati }\end{array}$ & 73 & 81 & 90 & Meningkat \\
\hline 7 & Dini Andriani & 70 & 80 & 84 & Meningkat \\
\hline 8 & $\begin{array}{l}\text { Dynda Kha- } \\
\text { risma }\end{array}$ & 71 & 84 & 86 & Meningkat \\
\hline 9 & $\begin{array}{l}\text { Farizki } \\
\text { Hasporo }\end{array}$ & 72 & 83 & 84 & Meningkat \\
\hline 10 & $\begin{array}{l}\text { Febrian } \\
\text { Pungky } \\
\text { Sandra }\end{array}$ & 73 & 82 & 83 & Meningkat \\
\hline 11 & $\begin{array}{l}\text { Jauharoh Has- } \\
\text { na Hamida }\end{array}$ & 70 & 80 & 85 & Meningkat \\
\hline 12 & Nadya Nastiti & 74 & 81 & 84 & Meningkat \\
\hline 13 & Naha Navisa & 72 & 82 & 85 & Meningkat \\
\hline 14 & $\begin{array}{l}\text { Nia Nur } \\
\text { Fadilla }\end{array}$ & 71 & 84 & 86 & Meningkat \\
\hline
\end{tabular}

\begin{tabular}{clcccc}
15 & $\begin{array}{l}\text { Nihaya Nur } \\
\text { Arifah }\end{array}$ & 74 & 80 & 87 & Meningkat \\
\hline 16 & $\begin{array}{l}\text { Prisca Fara- } \\
\text { dilla Rahma }\end{array}$ & 75 & 82 & 85 & Meningkat \\
\hline 17 & $\begin{array}{l}\text { Rifqi Hanif } \\
\text { Ramadhani }\end{array}$ & 70 & 84 & 90 & Meningkat \\
\hline 18 & $\begin{array}{l}\text { Salsabilla } \\
\text { Rahmadhanti }\end{array}$ & 70 & 80 & 85 & Meningkat \\
\hline 19 & $\begin{array}{l}\text { Silvi Sitavi- } \\
\text { ana }\end{array}$ & 70 & 83 & 84 & Meningkat \\
\hline 20 & $\begin{array}{l}\text { Syaifulizan } \\
\text { Nur Ikhsan }\end{array}$ & 71 & 81 & 85 & Meningkat \\
\hline 21 & $\begin{array}{l}\text { Syauqi } \\
\text { Mutha'illah }\end{array}$ & 75 & 80 & 90 & Meningkat \\
\hline 23 & $\begin{array}{l}\text { Tias Dwi } \\
\text { Maharani }\end{array}$ & 73 & 84 & 85 & Meningkat \\
\hline Mirawansya & 71 & 80 & 83 & Meningkat \\
\hline
\end{tabular}

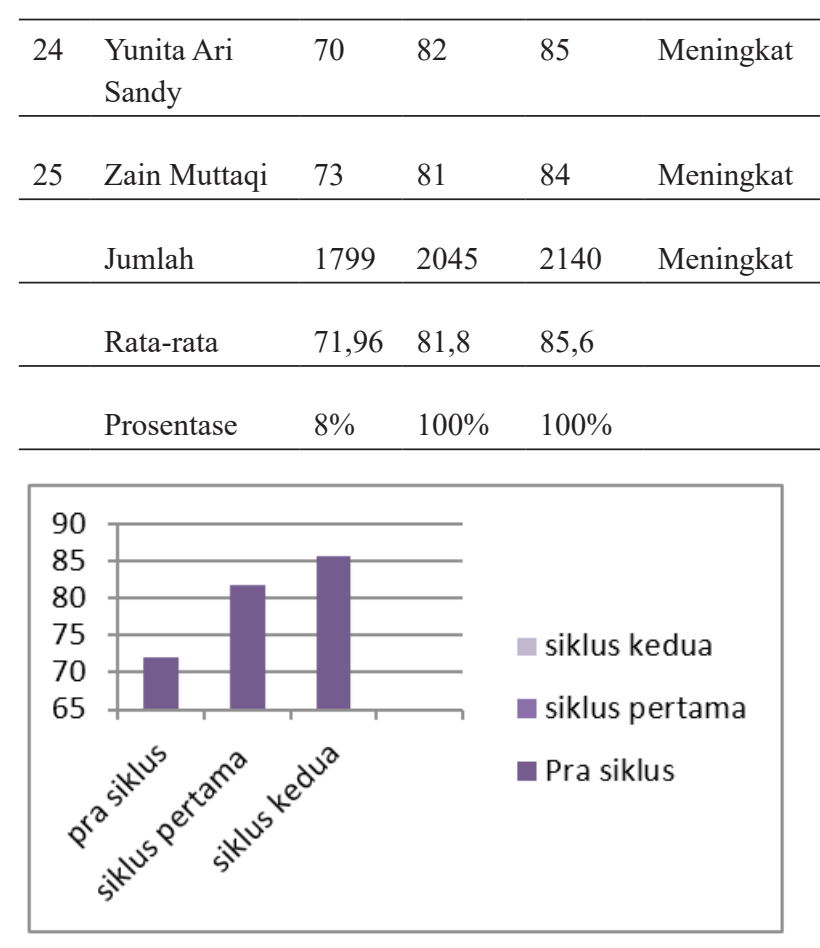

Nilai Hasil Pra siklus

Nilai rata-rata hasil belajar siswa sebelum menerapka metode eksperimen:

$$
\begin{aligned}
& \mathrm{M}=\sum_{\mathrm{N}}^{\mathrm{fx}}: \ldots \\
& \mathrm{M}=\sum_{25}^{1799}: \ldots \\
& \mathrm{M}=71,96
\end{aligned}
$$

Persentase ketuntasan hasil belajar sebelum menerapkan metode eksperimen:

$$
\begin{aligned}
\mathrm{T}=\underline{\mathrm{X}} \times 100 \% \\
\mathrm{~T} \\
\mathrm{~T}=\underline{\underline{2}} \times \frac{\mathrm{2}}{25} 100 \% \\
\mathrm{~T}=8 \%
\end{aligned}
$$

Nilai Siklus pertama

Nilai rata-rata hasil belajar siswa setelah menerapkan metode eksperimen

$$
\begin{aligned}
& \mathrm{M}=\sum_{\mathrm{N}}^{\mathrm{fx}}: \ldots \\
& \mathrm{M}=\sum_{25}^{2045}: \ldots \\
& \mathrm{M}=81,8
\end{aligned}
$$

Persentase ketuntasan hasil belajar setelah menerapkan metode eksperimen

$$
\begin{aligned}
\mathrm{T}= & \underline{\mathrm{X}} \times 100 \% \\
\mathrm{~N} & =\frac{25}{25} \times 100 \% \\
\mathrm{~T} & =100 \%
\end{aligned}
$$

Nilai Siklus kedua 
Nilai rata-rata hasil belajar siswa setelah menerapkan metode eksperimen

$$
\begin{array}{l:l:}
\mathrm{M}=\sum_{\mathrm{N}}^{\mathrm{fx}} & \ldots \\
\mathrm{M}=\sum_{25}^{2140} & \ldots \\
\mathrm{M}=85,6
\end{array}
$$

Persentase ketuntasan hasil belajar setelah menerapkan metode eksperimen

$$
\begin{aligned}
\mathrm{T} & =\frac{\mathrm{X}}{\mathrm{N}} \times 100 \% \\
\mathrm{~T} & =\frac{25}{25} \times 100 \% \\
\mathrm{~T} & =100 \%
\end{aligned}
$$

Hasil analisis penilaian belajar siswa untuk meningkatkan hasill belajar siswa diperoleh nilai pre tes yaitu dengan rata-rata 71,96, dan dengan menggunakan metode eksperimen untuk siklus pertama diperoleh nilai rata-rata 81,8 , sedangkan dengan menggunakan metode eksperimen untuk siklus kedua diperoleh nilai rata-rata 85,6. Ini berarti dengan metode eksperimen untuk meningkatkan hasil belajar siswa pada menggambar realis mengalami peningkatan. Guru dikatakan berhasil dengan baik dalam pembelajaran gambar realis menggunakan metode eksperimen.

\section{SIMPULAN}

Dengan jumlah siswa yang terdaftar pada kelas VIII B sebanyak 25 siswa yang terdiri dari 17 putri dan 8 siswa putra. Sebelum di terapkan metode eksperimen dilakukan Pre test praktek menggambar realis diperoleh total nilai 1799 dengan nilai rata-rata 71,96 dan siswa yang tuntas belajar dalam pembelajaran menggambar realis sebelum diterapkan metode eksperimen hanya 2 orang dengan nilai 75 dengan persentase ketuntasan belajar 8\%. Maka dikatakan pembelajaran menggambar realis belum berhasil dalam memenuhi nilai ketuntasan belajar.

Penerapan Metode Eksperimen dilakukan dengan dua siklus dan didapat dua hasil penilaian. Penerapan metode eksperimen itu sangat efektif dalam membantu siswa mempelajari dan membuat gambar realis dengan baik. Sebelum mengajar, guru melakukan persiapan mengajar dengan menyusun program tahunan, program semester, RPP, silabus. Proses pembelajaran dalam penerapan metode eksperimen dilakukan empat tahapan yaitu: Percobaan awal, Pengamatan, Hipoteis awal, Verifikasi, Aplikasi konsep, Evaluasi. Dengan mengadakan pengamatan melalui angket dan observasi langsung dengan guru Seni Budaya serta siswa kelas VIII B.

Setelah menggunakan metode eksperimen mulai dari siklus pertama dan siklus kedua, didapatkan nilai rata-rata pada siklus pertama 81,8 , dan nilai rata-rata pada siklus kedua 85,6 dengan ini membuktikan adanya peningkatan nilai sebanyak 3,8. Hasil penyebaran angket siswa dan guru mengenai langkah-langkah mereka dalam menggunakan metode eksperimen membuktikan bahwa mereka sudah melakukan metode tersebut dengan baik. Hasil pengamatan observasi siswa dan guru membuktikan siswa dan guru juga sudah melakukan proses metode eksperimen dengan baik dan dengan hasil memuaskan. Penemuan pada penelitian ini yaitu, metode eksperimen dalam pembelajaran menggambar realis ini lebih efektif digunakan daripada metode yang digunakan sebelumnya yaitu metode diskusi.

\section{DAFTAR RUJUKAN}

Hurlock, E.1978. Psikologi Perkembangan Anak : Suatu Pendekatan Sepanjang Rentang Kehidupan. Edisi kelima: Jakarta : Erlangga.

Hurlock, E.1980. Psikologi Perkembangan Anak : Suatu Pendekatan Sepanjang Rentang Kehidupan. Edisi kelima: Jakarta : Erlangga.

Sagala, H. Syaiful, 2009. Konsep dan Makna Pembelajaran. Bandung: Alfabeta.

Sudjana, Nana. 2005. Penilaian Hasil Proses Belajar Mengajar. Bandung: Remaja Rosdakarya

Sugiyono. 2011. Metode Penelitian Kombinasi.Bandung:Alfabeta

Sumanto. 2008. Pembelajaran Seni Rupa di Sekolah Dasar. Malang:Rasindo.

Syaodih N.S,1997.Pengembangan Kurikulum Teori dan Praktek. Bandung:Remaja Rosdakarya 